\title{
Symbolická moc médií jako pedagogický faktor
}

\author{
Petr Valenta \\ Univerzita Karlova, Filozofická fakulta, Katedra pedagogiky
}

Redakci zasláno 19. 6. 2013 / upravená verze obdržena 4.12.2013 /

k uveřejnění přijato 7.1.2014

\begin{abstract}
Abstrakt: Cílem teoretické studie je zmapovat symbolickou moc jako podmínku a zároveň hlavní prostředek edukačně socializačního působení médií. V úvodu studie je stručně představen koncept symbolické moci, z něhož autor vyvozuje existenci specifického „Vzdělávacího programu“ médií. V druhé části je diskutována role státu v utváření symbolického prostředí a je argumentováno, že parametry „vzdělávacího programu“ médií dominantně definuje stát jako hegemon symbolické moci. Možnosti vytváření opozičních diskursů potenciálně narušujících symbolickou hegemonii státu a role, kterou v tomto procesu hraje mediální výchova, jsou tématem části následující. Na závěr příspěvku je pak formulována představa mediální gramotnosti jako sociální a občanské kompetence, která jednotlivcům umožní účinněji se zapojit do procesu veřejné komunikace a politického rozhodování. Oproti tradiční představě, že média jsou hegemonem symbolické moci, předkládá příspěvek teoreticky podloženou tezi, že symbolická moc médií je kontrolována státem, který určuje obsah a podoby veřejného diskursu. „Vzdělávací program“ médií je proto nastolován státem a odráží jeho potřeby kontrolovat vědění ve společnosti. S ohledem na tato zjištění by mediální výchova mohla rozšířit současné pojetí mediální gramotnosti o občanský a politický kontext. Pokud jsou média primárně doménou ovládání, vědomosti a dovednosti spojené s médii by měly vytvářet přesnější představu o způsobech uplatňování moci ve společnosti a formách emancipace vůči ní.
\end{abstract}

Klíčová slova: symbolická moc, média, ideologie, diskurs, institucionální moc, mediální pedagogika, mediální gramotnost

Představy o vlivu médií na člověka procházely v průběhu historie často protikladným vývojem. Přesvědčení o mocných médiích typické pro první polovinu 20. století bylo pod vlivem psychologického a sociologického výzkumu v 50. a 60. letech postupně nahrazeno přesvědčením o spíše omezeném vlivu médií. Od 70. let se pak mediální teorie opět vrací k představě o médiích sice mocných, ale působících na publikum, které je schopno nežádoucím účinkům médií čelit (srov. Jirák \& Köpplová, 2007, s. 161-171). Na tento vývoj reagovala také mediální výchova, která se postupně zbavila své výlučně ochra- 
nitelské funkce a dnes je spíše emancipačním projektem rozvoje mediální gramotnosti jako souboru kompetencí pro aktivní a autonomní život v medializované ${ }^{1}$ společnosti.

Samotná existence mediální výchovy je projevem uznání moci masových médií a jejich schopnosti působit na jedince a celou společnost. V základu mediálně pedagogického působení je přesvědčení o mocných médiích a z něho vyplývající potřeba připravovat již od útlého věku jednotlivce na soužití s nimi. Pro mediální výchovu (mediální pedagogiku²) je porozumění mediální moci zásadní z hlediska formulace cílů a strategií zmocňování, emancipace a zvyšování rezistence jedince vůči vlivům masových médií. Jak tedy můžeme mediální moc chápat?

\section{Symbolická moc}

Základní vlastností, kterou médiím přisuzuje mediální teorie, je schopnost vytvářet významy a zprostředkovávat je publiku (srov. McQuail, 2009, s. 87). Prostřednictvím kontroly informačních toků mohou média ovlivňovat obsah společenské diskuse, tedy i myšlení, postoje a chování lidí. Vzhledem k těmto schopnostem jsou média považována za klíčové instituce symbolické moci.

Bourdieu (1995, s. 231) označuje pojmem symbolická moc takovou formu moci, která umožňuje prosazovat subjektivní hledisko určité skupiny do společenského diskursu jako objektivně pravdivý popis reality a donutit ostatní přijmout její pohled na sociální realitu. Předpokladem symbolické moci je vlastnictví symbolického kapitálu, tj. koncentrované sociální autority odrážející uznání přisuzované společností určitým jedincům. Symbolická moc je pak uplatňována prostřednictvím konkrétních forem užívání jazyka v sociální praxi. ${ }^{3}$

Pojem medializace je zde užit ve významu, který mu přisuzuje Schulz (2004).

2 Pojmy mediální výchova a mediální pedagogika jsou užity v souladu s německým modelem oboru, kde mediální výchova představuje subdisciplínu mediální pedagogiky jako uceleného vědního oboru zkoumajícího široký kontext vztahů mezi médii a edukací (podrobněji viz Sloboda, 2006, s. 36-37).

3 Zkoumáním vztahu mezi užíváním jazyka a mocí se zabývá např̀. kritická diskursivní analýza. Diskurs chápe jako způsob užívání jazyka určitou sociální skupinou v určité situaci, přičemž ta skupina, která diskurs ovládá, má schopnost kontrolovat postoje a pohledy lidí na danou situaci. Mocenský boj ve společnosti se vede o kontrolu nad diskursem, resp. o to, kdo bude určovat pravidla diskursu, od nichž se odvozují sociální pravidla a normy (srov. Fairclough, 2001, s. 121-138; Wodak, 2002, s. 5-31). 
Bourdieuho koncept převzal Thompson (2004), podle něhož symbolická moc umožňuje jejím držitelům „zasahovat do toku dění, ovlivňovat jednání ostatních ... i vytvářet události tím, že vyrábějí a přenášejí symbolická sdělení (s. 17). Média se jako významný aktér sociální komunikace podílejí na vytváření symbolického prostředí tvořícího definiční rámec pro individuální vnímání reality. Společenská autorita médií vyplývá z jejich postavení hegemona symbolické komunikace, který má exkluzivní př́stup k informacím a informačním zdrojům. Tato exkluzivita na jedné straně umožňuje médiím určovat, co věci jsou a nejsou, a upevňovat určité představy o světě, na straně druhé posiluje závislost publika na médiích jako zdrojích poznání těch aspektů reality, které přesahují bezprostřední zkušenost jednotlivců. Média tak mohou výběrem informací, jejich dávkováním a výkladem korigovat myšlení a postoje veřejnosti, tedy uplatňovat symbolickou moc.

\section{Vzdělávací program médií}

Popsané parametry uplatňování symbolické moci médií se pozoruhodně podobají formám a charakteru výchovně-vzdělávacího působení pedagoga. V tradičním transmisivním modelu vzdělávání představuje učitel informační autoritu disponující přístupem k vědomostem, které jsou žákům zatím nedostupné. Učitel pojmenovává realitu, co řekne, se stává objektivní pravdou. Formovat myšlení žáků o světě a zpřesňovat jejich chápání reality v souladu s objektivní (vědeckou) pravdou je jedním z hlavních úkolů pedagoga. Pedagogický proces je tedy možné chápat jako proces uplatňování symbolické moci učitele nad žáky. Z pedagogického pohledu představuje proto symbolická moc faktor ${ }^{4}$, díky němuž mohou média vstupovat do edukačně-socializačního procesu a realizovat svůj specifický „vzdělávací program“.

„Vzdělávací program“ médií může zahrnovat produkty určené ke vzdělávání publika (a za tím účelem vytvářené), většinou je však zprostředkován nepřímo, způsoby, jimiž je v mediálním diskursu vykreslována realita. Tyto způsoby jsou relativně stálé, protože do značné míry vyplývají z organizace pracovních vztahů uvnitř mediálních společností a ustálených rutin tvorby mediálních sdělení. Novináři pracují s řadou abstraktních kategorií (žurnalistické žánry, zpravodajské hodnoty), které vstupují do procesu výběru zpráv

4 Termín faktor je zde užit v souladu s pojetím německých autorů Hüthera a Schorba (2005, s. 381-389), kteří označují média za faktor edukačně-socializačního působení tehdy, když k ovlivnění jednotlivců dochází spíše nepř́mo, nereflektovaně a na straně objektu ovlivnění často neuvědomovaně. 
a formují podobu mediálních sdělení. Řídí se při tom morálkou či hodnotami, které jsou explicitně (jako závazný etický kodex) nebo implicitně (jako soubor obyčejů vyplývající z praxe) součástí žurnalistické profese. Ustavený systém norem, hodnot a postupů řídící každodenní žurnalistickou praxi je výsledkem historických bojů mezi tendencí státu integrovat média do vlastních institucionálních struktur a kontrolovat informační tok ve společnosti a přirozenou potřebou novinářủ zachovat si autonomii. Žurnalistická morálka je objektivizací subjektivních představ o fungování médií té síly, která se v těchto bojích dokázala prosadit. Zpětně však ovlivňuje novinářovo vnímání vlastní profese, formuje jeho profesní identitu a vytváří pohled na svět, který je novinářům společný. Ten se jako určitý druh ideologie projektuje zpět do mediální tvorby a zajištujuje relativní stabilitu mediálního způsobu zobrazování reality.

Ideologie je proto hlavním nositelem a definičním parametrem „vzdělávacího programu“ médií. Definuje jeho ideově-hodnotovou orientaci, obsah i cíle jeho pedagogického působení a zároveň zajištuje stabilitu mediálních forem ovlivňování. Protože je však hluboce vtělena do činností spojených s každodenní žurnalistickou praxí, nelze ji chápat pouze jako vědomý konstrukt včleňovaný do mediálních sdělení za účelem prosazení partikulárního hlediska nebo zájmu daného média. Řada procesů, které mediální praxi ovlivňují (vzdělávání budoucích novinářů, tvorba mediální legislativy, rozvoj technologií), se uskutečňuje mimo média samotná. Média jsou tak zapletena do přediva institucionálních vztahů, v nichž probíhají mnohé další diskursy a působí rozličné ideologie. To mimo jiné znamená, že charakter „vzdělávacího programu" médií není formován pouze médii samotnými, ale je spíše výsledkem interakcí mezi nimi a dalšími sociálními institucemi, se kterými média vstupují do vzájemných vztahů.

\section{Stát jako hegemon symbolické moci}

Bourdieu (1998, s. 81) považuje za místo, kde se symbolická moc koncentruje především, stát. Moderní stát je schopen koncentrovat symbolický kapitál, protože ovládá klíčové sociální instituce (rodina, vzdělávací a právní systém atd.), které organizují život jednotlivce ve společnosti a podílejí se na jeho socializaci. S těmito institucemi se pojí řada „oficiálních aktů či diskursů, které mají symbolickou účinnost, nebot' jsou založeny na autoritě ... oficiálních vykonavatelů..." (tamtéž, s. 86). Oficiální akty „vytvářejí (či nastolují) společ- 
ností garantovanou sociální identitu“, z čehož plyne moc státu „autoritativně prohlašovat, čím určité bytí, věc či osoba, ve skutečnosti, ve své legitimní sociální definici je, to jest, čím je oprávněna být, jaké sociální bytí má právo si osobovat" (tamtéž, s. 86). Symbolická moc státu se tedy prosazuje a upevňuje prostřednictvím podílení se na sociálních rituálech spojených s institucemi státu: „Stanovováním určitého rámce praktickým činnostem stát zároveň nastoluje a vštěpuje společné formy a kategorie vnímání a myšlení (tamtéž, s. 88). Prostř̌ednictvím oficiálních aktů ustavení (soudní verdikty, matriční záznamy, rituály spojené se studiem atd.) jsou subjektivní hlediska těch, kdo ovládají instituce státu, objektivizovány a stávají se sociální normou. Tyto normy jsou zachovávány a zprostředkovávány v institucích státu (jako je napřr vzdělávací systém), přičemž se vytrácí vědomí jejich sociálního původu a jsou chápány jako objektivní, tedy přirozená a samozřejmá kritéria fungování společnosti. Takto symbolická nadvláda státu definuje ideologický rámec umožňující socializovat jednotlivce do jednotného systému hodnot a idejí, které odpovídají potřebám vládnoucího řádu.

Vytváření jednotných kategorií myšlení je důležitým prostředkem stabilizace moci. Foucault (1984) konstatuje, že moc je utvářena prostřednictvím obecně přijímaných forem vědění:

Každá společnost disponuje režimem pravdy, obecnou politikou pravdy, tedy typem diskursu, který ji (pravdu) přijímá a umožňuje působit jako pravdivé; mechanismy a instancemi, jež umožňují rozlišovat pravdivá a nepravdivá tvrzení; ... statusem těch, kteří jsou oprávněni ř́kat, co je a co není pravdivé. (s. 73)

Moc závisí na vědění, které vytváří a klasifikuje jednotlivce do určitých specializovaných oblastí vědění, má schopnost integrovat nebo vylučovat. Pravda je výsledkem „vědeckého diskursu“, který je živen a podporován státem. Je šířena dominantně prostřednictvím vzdělávacího systému a médií, které jsou důležitými politickými a ekonomickými institucemi státu. Takzvané „boje o pravdu“ se nevedou o nalezení skutečné pravdy, ale o to, kdo bude kontrolovat pravidla, podle kterých je rozlišována pravda od lži, kdo bude dávat vědění status pravdivosti a určovat, jaké funkce pravda ve výkonu moci plní. Vědění tak odvozuje svoji autoritu od stávajících mocenských vztahů: „Moc ve skutečnosti produkuje; produkuje realitu; produkuje oblasti objektů a rituálů pravdy“ (Foucault, 2000, s. 274). 


\subsection{Skryté kurikulum státu}

Ideologické působení státu je ekvivalentem „skrytého kurikula“ v kontextu vzdělávání. Skryté kurikulum státu tvoří kulturní obsahy (hodnoty, postoje, ideologie), které se prostřednictvím institucí symbolické moci (systému školního vzdělávání a masových médií) dostávají do povědomí jednotlivců a strukturují jejich myšlení. Pro svou univerzalitu a zdánlivou objektivitu jsou neidentifikovatelné jako sociální konstrukty, které jsou konkrétním výsledkem působení symbolické moci ve společnosti. Jsou kulturně sdílenými pravdami nabývajícími objektivní platnosti, předávanými a upevňovanými v procesu socializace.

Významnou úlohu v tomto procesu hraje jazyk. Jazyk jako znakový systém slouží k odkazování k významům, které připisujeme reálným jevům nebo předmětům. Tyto významy jsou ve své podstatě subjektivní (odkazují na zkušenost tady a ted'), nicméně díky jazyku je můžeme sdílet s druhými lidmi. Aby byla naše subjektivita srozumitelná ostatním, používáme abstrakce, které nám dává jazyk. Vzniká tak jakási obecná, objektivizovaná zkušenost, která může být zachována $\mathrm{v}$ čase a zprostředkována napříč generacemi. $\mathrm{K}$ té se potom odkazujeme jako k platné realitě, aniž si uvědomujeme, že významy, které jí přisuzujeme, jsou sociálně dohodnuté - konstruované (srov. Berger \& Luckmann, 1999, s. 41-46).

Novináři mají tendence vnímat realitu ze subjektivního (přesněji řečeno intersubjektivního ${ }^{5}$ ) hlediska své socioprofesní skupiny a tuto ideologickou předpojatost do svých sdělení projektovat:

žurnalistika ... je ve své podstatě ideologickou záležitostí - je to komunikační nástroj, jímž se k publiku (úmyslně či neúmyslně) přenášejí nejen fakta, ale i předpoklady, postoje a hodnoty tvůrců, jež jsou odvozeny z jejich světového názoru a současně jej i vyjadřují. (McNair, 2004, s. 13)

Každé mediální sdělení je ideologicky předpojaté do té míry, nakolik sami novináři podléhají ideologii sdílené danou kulturou, společností či socioekonomickou skupinou, přičemž ideologie sama je produktem „skrytého kurikula“, jehož kontury formuje stát jako hegemon symbolické moci.

5 Intersubjektivita odkazuje na tu část reality, která je členům dané socioprofesní skupiny společná. Ačkoliv člověk vnímá realitu subjektivně, tj. připisuje jejím jednotlivým aspektům různé významy, existuje řada významů, o kterých jsou si jednotlivci vědomi, že je chápou ve shodě s druhými (Berger \& Luckmann, 1999, s. 28-29). V případě novinářủ může existovat shoda v náhledech na některé aspekty reality, jelikož sdílejí podobný socioekonomický status či původ, relativní společenskou prestiž a autoritu, moc ovlivňovat společenský diskurs atd. 
„Vzdělávací program“ médií je tedy převážně výsledkem ideologického působení státu, který definuje parametry „objektivní“ reality. Proto není ideologie v médiích v rozporu s principem žurnalistické objektivity. Symbolická hegemonie státu umožňuje novinářům odkazovat se právě na stát jako garanta pravdy, přičemž stát samotný se jako byrokratizovaný a formalizovaný institucionální systém jeví být objektivním (srov. McChesney, 2001, s. 31). Teprve až zpochybnění objektivity státu vytváří konflikt s žurnalistickou objektivitou. Princip objektivity nabývá v tomto kontextu podobu institutu sociální kontroly uplatňované na novináře proto, aby nevybočili z ideologického rámce, který nastoluje stát. Právě v tomto ideologickém působení, nikoliv snad v produkci vzdělávacích obsahů, spočívá nejvýznamnější pedagogická síla médií.

\subsection{Kontrola médií jako podmínka vlády}

Rozvoj technických prostředků sdělování symbolickou hegemonii vládnoucích elit dále posílil. Mocenská elita může s pomocí masových médií prosazovat konkrétní interpretace reality odpovídající jejím zájmům a potřebám efektivněji, flexibilně je měnit v závislosti na vývoji situace, mobilizovat nebo utlumovat politickou aktivitu veřejnosti. Symbolická moc tak plynule přechází v moc politickou, je její stabilní součástí a také podmínkou. Přesto Thompson (2004) rozeznává několik předpokladů, které musí na straně držitele symbolické moci nastat: (a) držitel musí disponovat rozvinutou komunikační kompetencí, tedy mít „dovednosti, schopnosti a znalosti nezbytné pro produkci, přenos a přijímání informací..." (s. 20); (b) musí být nositelem vysoké společenské prestiže či autority; (c) musí mít přistup k technickým prostředkům přenosu sdělení.

Ačkoliv jednotlivci mohou mít rozvinuté komunikační dovednosti a schopnost využívat rozličné komunikační kanály, veřejnost jako taková je př́liš roztř́šstěná na to, aby byla schopna formulovat jednotné sdělení a prosadit je do masových médií. ${ }^{6}$ I když určité sociální skupiny mohou disponovat vysokou společenskou prestiží a autoritou, symbolickou mocí ve veřejném dis-

6 To může souviset se skutečností, že vědění je ve společnosti distribuováno sociálně, tj. na základě př́slušnosti k socioprofesním rolím a skupinám. Přestože existuje suma obecně relevantního vědění, pro výkon každé sociální role je zapotřebí osvojit si poněkud odlišné kategorie vědomostí a dovedností. Vědomí člověka je tedy sociálně předurčeno rolemi, které zastává (srov. Berger \& Luckman, 1999, s. 74-80). Ačkoliv jednotlivci mohou sdílet obecné pojetí reality, rozdíly $\mathrm{v}$ individuálním pojetí mohou být tak veliké, že to zabraňuje jejich schopnosti nacházet společné zájmy a formulovat společné potřeby ve veřejném diskursu. 
kursu disponují pouze některé z nich (srovnej učitele a poslance). Komunikační kompetence ani sociální prestiž tedy ještě nezaručují, že jejich nositelé disponují symbolickou mocí. Zdá se, že ze tří výše uvedených předpokladů je pro symbolickou moc klíčový především přístup do masových médií.

Zajištění kontroly nad přístupem ke komunikačním prostředkům, resp. nastolení bariéry mezi producenty a konzumenty symbolických sdělení, je pro udržení privilegovaných pozic elit v mocenské struktuře státu zásadní:

Omezením př́stupu k písemnostem byla vybudována hranice mezi uživateli písma a těmi, kteří jsou z jeho užívání vyloučeni. Písmo bude tedy nepřetržitě sloužit převážně jako prostředek politického a kulturního ovládání. Zůstane vyhrazeným nástrojem správní moci a oficiální ideologie. (Lohisse, 2003, s. 40)

Ačkoliv je zde popisována situace $v$ Číně na přelomu prvního tisíciletí před naším letopočtem, totéž platí o tisku a elektronických médiích současné doby. Současná média neomezují přístup publika ke sdělením, která produkují, systém jejich organizace a řízení však vylučuje rozsáhlé společenské skupiny z podílu na jejich aktivním utváření ve prospěch dominantních diskursů nastolovaných mocenskou elitou. To má své společenské i pedagogické důsledky. Nemožnost artikulovat potřeby a hlediska v celospolečenském diskursu př́mo zakládá systém sociální nerovnosti. Ti, kteří nemají hlas, mohou být odsunováni na okraj společenského rozhodování o záležitostech sociálního celku, do nějž také náleží. Namísto autonomního subjektu politické moci se stávají jejím objektem. Naopak ti, kteří si dokáží zajistit př́istup do médií jako producenti sdělení, získají moc potvrzovat tuto nerovnost prostřednictvím symbolických reprezentací jako stav přirozený a objektivně neměnný. Tím zpětně posilují svoji politickou moc. Z pedagogického pohledu unifikace sdělení v zájmu politické moci formuje veřejnost konformní a pasivní ke svému stavu podřízenosti vládnoucí moci, což je zřetelně v rozporu s obecnými cíli vzdělávání.

\subsection{Média jako nástroj moci}

Pokud moc otevírá cesty k ovládnutí komunikačních prostředků a současně kontrola médií zpětně moc upevňuje, dochází nikoliv ke štěpení moci, ale $\mathrm{k}$ její koncentraci. Tvrzení typu „média v demokratické společnosti slouží jako prostředek veřejnosti, který jí pomáhá být rovnocenným partnerem politiky“ (Pospíšil \& Závodná, 2009, s. 58), jsou proto zavádějící. Stejně tak nelze a priori předpokládat, že média jsou antitezí státní moci pouze proto, 
že tisk kdysi sloužil k „šsiřření názorů a poznatků, které zpochybňovaly tradiční rozdělení moci“, a tedy si "tento politický rozměr mediální komunikace média nesou dodnes" (Jirák \& Mičienka, 2007, s. 19).

Je pozoruhodné, jak mýtus médií jako významné demokratické síly ve společnosti přetrvává $\mathrm{v}$ myšlení některých mediálních pedagogů, aniž by byl revidován aktuálními poznatky prokazujícími úzkou vazbu mezi vlivnými médii a představiteli hospodářské a politické moci. ${ }^{7}$ Komerční podstata médií, úzké vazby mediálních korporací na mocenské elity, personální propojení s oficiálními institucemi státu a trhu, vliv inzertního průmyslu na obsah mediálních sdělení, princip objektivity a další faktory ukazují, že zodpovědnost mediálních korporací leží jinde než v podpoře demokratického rozvoje společnosti.

Pokud mocenská elita drží dominantní podíl symbolické moci ve společnosti, pak je také schopna nastolovat významy obsahům přenášeným v rámci mediálního diskursu a kontrolovat strukturu témat, idejí a hodnot, které se stávají „,vzdělávacím programem“ médií. Skutečnost, že média jsou nástrojem moci, odhaluje základní úlohu tohoto „vzdělávacího programu“: legitimizaci sociální a mocenské nerovnosti v moderní kapitalistické společnosti prostřednictvím symbolické a ideologické manipulace využívající komunikační systémy médií.

\section{Mediální pedagogika v procesu posilování symbolické moci jedince}

Je proto na místě revidovat obecnou představu o médiích jako hlídacím psu demokracie, a to především v materiálech určených studentům a pedagogům mediální výchovy. Stejně tak je třeba znovu promyslet obecnější cíle mediální výchovy. Je chvályhodné, že mediální výchova usiluje o aktivizaci jedince ve vztahu k médiím. Existuje ale riziko, že se vyčerpá v prostém nácviku tvorby žurnalistického sdělení, př́padně v osvojování si akademických znalostí o médiích, aniž by byl stanoven jasný cíl těchto aktivit (bohužel dosud není $\mathrm{k}$ dispozici relevantní studie, která by se zabývala formami implementace mediální výchovy v českých školách). Otázka, k čemu mají studenti získané znalosti a dovednosti využít, není v současné české koncepci mediální vý-

7 Podrobněji viz Herman \& Chomsky (2002, s. 8-12), Rouse, Thornton, \& Walters (2006, s. 253-271). 
chovy stále uspokojivě zodpovězena. Právě koncept symbolické hegemonie mocenské elity se tak může stát paradigmatem pro mediálně pedagogickou analýzu „vzdělávacího programu“ médií a pro následné úvahy o cílech, strategiích a obsahu mediální výchovy. Základním cílem mediálně pedagogických aktivit by pak byl rozvoj kompetencí umožňujících proniknout do mediálního diskursu v zájmu posílení individuální symbolické, resp. politické moci, jako předpokladu pro aktivizaci veřejnosti v úsilí o spravedlivější a demokratičtější společnost.

Předpoklad pro naplnění takového cíle spočívá v přesvědčení, že symbolická moc není výsadou pouze mocenské elity, ale že subjekty uplatňující symbolickou moc je možné najít na všech úrovních společenské organizace. Lazarsfeldův výzkum ukázal, že na interpersonální a skupinové úrovni působí tzv. názoroví vůdci interpretující oficiální sdělení získaná z médií z pohledu vlastní socioprofesní skupiny a ovlivňující mínění a postoje členů dané komunity (podrobněji viz Berelson, Gaudet, \& Lazarsfeld, 1944, s. 106-107). Tyto autority jsou potenciálně schopné narušovat dominantní diskursy a činit je submisivními vůči vlastním interpretacím. To znamená, že na nižších úrovních sociální organizace participují na symbolické moci také jednotlivci. Podobně uvažuje také Gramsci (1959, s. 7-27), který navrhuje jako prostředek emancipace marginalizovaných skupin posílení vlivu lokálních intelektuálních autorit při vytváření kontra-ideologií vůči ideologii vládnoucí elity.

Zatímco na nižších úrovních organizace se symbolická moc váže $\mathrm{k}$ jednotlivcům a zachovává si relativně pluralitní charakter (dominantní diskursy jsou zde neustále konfrontovány s opozičními diskursy), na celospolečenské úrovni se depersonifikuje, institucionalizuje a stává se nástrojem prosazování ideologie v masovém měřítku. Pakliže na nižších rovinách komunikace je symbolická moc demokratizačním prvkem, na celospolečenské (institucionální) úrovni se stává nástrojem dominance. Je proto třeba přenést symbolickou moc jednotlivců na celospolečenskou úroveň, poskytnout hlas těm, kdo jsou z mediálního diskursu vyloučeni, aby byl zajištěn jejich podíl na demokratické moci.

\subsection{Digitální diskurs a společnost sítí}

Digitální média rozšiřují komunikační možnosti jednotlivců, umožňují větší míru participace na společenské diskusi a zajištujuí větší rovnoprávnost komunikujícím aktérům. Bezhraniční sféra internetu povyšuje individuální 
sdělení na celospolečenskou a globální úroveň. Vzniká tak nový typ diskursu komplexně ovlivňující sociální strukturu, kulturu, ekonomickou produkci i formy uplatňování moci odehrávající se nyní dominantně uvnitř a prostřednictvím sítí. Digitální diskurs může potenciálně zaujmout místo v opozici vůči dominantnímu diskursu tradičních médií a přispívat $\mathrm{k}$ demokratizaci společnosti (podrobněji viz Lévy, 2000, s. 115). Současně má však tendence selektovat jednotlivce, sociální skupiny či společnosti na základě jejich schopnosti přizpůsobit se logice sítí (srov. Castells, 2004, s. 138-149).

Nízká disponibilita potřebnými technologiemi a dovednostmi spojenými sjejich užíváním jsou rozsáhlým zdrojem vylučování. Ohroženi jsou především lidé s nízkými příjmy, málo kvalifikovaní, příslušníci některých etnických menšin. Nemožnost nebo neschopnost podílet se na sít’ové komunikaci vede $\mathrm{v}$ jejich př́padě $\mathrm{k}$ vylučování $\mathrm{z}$ ekonomických a sociálních aktivit (srov. Kruger, 1997, s. 64-65). Pro tyto skupiny nejsou digitální technologie zdrojem emancipace, ale sekundárního vyloučení. Moc utvářet a ovlivňovat diskurs v kyberpostoru tak stále náleží především bohatším a vzdělanějším prríslušníkům vyšších sociálních vrstev. Přesto jsou jeho obsah a podoby neustále podrobovány státní cenzuře, at' už přímé (blokováním přístupu k určitým obsahům), nebo nepřímé (prostřednictvím zákonů přenášejících odpovědnost za obsah na poskytovatele internetových služeb nebo jejich uživatele) (podrobněji viz Bambauer, 2012). Cenzura je navíc doprovázena rozsáhlým monitoringem komunikačních aktivit uživatelů internetu (viz kauza Snowden). Internet tedy stále zůstává doménou mocenského ovládání.

\subsection{Digitální média jako nástroj emancipace}

Nerovnost v př́stupu k internetu (digital divide) je v posledních letech uvažován jako sociálně-politický problém globálního charakteru. V roce 2011 OSN zařadila přístup $\mathrm{k}$ internetu mezi základní lidská práva. Pirátské hnutí požadující svobodný přístup k obsahům internetu má své zastoupení v evropském parlamentu. Důležitou roli v odstraňování této nerovnosti může sehrát škola, pokud by byla schopna garantovat přístup k internetu nejen pro žáky a studenty, ale také pro veřejnost v rámci místní komunity. Prostřednictvím vzdělávacích programů se může škola podílet na rozvoji technických dovedností spojených s užíváním digitálních médií jako nezbytného předpokladu zapojení se do digitální komunikace. Mediální pedagogové by měli kriticky reflektovat široké aspekty působení médií (včetně internetu), symbolické moci a obecně uplatňování moci ve státě a vést $\mathrm{k}$ této reflexi studenty. Roz- 
víjení kompetencí spojených s užíváním komunikačních médií by mělo být vedeno záměrem vzbuzovat vưli k aktivnímu zapojování se do procesu společenské komunikace $\mathrm{v}$ zájmu formulování vlastních stanovisek ve veřejném diskursu (např. formou blogů nebo tzv. lidové žurnalistiky) a posílení účasti na občanském a politickém dění ve společnosti. Těmito schopnostmi vybavení jedinci by pak postupně v rámci svých sociálních komunit přebírali role názorových vůdců a zprostředkovávali klíčová témata společnosti dovnitř daných sociálních celků, stejně jako formulovali potřeby a mínění zásadní pro život dané komunity směrem $\mathrm{k}$ většinové společnosti. To by umožnilo zapojit dosud marginalizované skupiny do procesu celospolečenské diskuse a zvýšit jejich podíl na politickém rozhodování.

\subsection{Nová mediální gramotnost}

Posílení symbolické moci jednotlivců jejím přenesením na úroveň celospolečenskou vyžaduje jako cíl mediální výchovy rovněž proměnu chápání mediální gramotnosti. Současné úzké pojetí mediální gramotnosti jako specifické komunikační kompetence (podrobněji viz Aufderheide, 1992) může být nahrazeno širším konceptem občanské, politické a sociální gramotnosti založené na vědomí mediální determinace sociální skutečnosti a zahrnující škálu postojů a jednání směřující $\mathrm{k}$ úsilí o vytvoření sociálně spravedlivější demokratické společnosti.

Mediální pedagogika se může stát hybatelem společenských změn, pochopíli správně vztah mezi symbolickou a politickou mocí. Měla by být schopna vyvozovat na základě poznatků o fungování soudobých médií závěry týkající se kvality širšího společenského uspořádání, jehož jsou média součástí. Deformované procesy uvnitř samotných médií jsou důsledkem selhání principů výkonu demokratické moci, která je v informační společnosti prezentována, legitimizována a uplatňována prostřednictvím médií. Pokud chce mediální výchova přispět ke „snížení rizik, jež mediální produkce představuje“ (RVP G, 2007, s. 78), měla by být schopna odhlédnout od médií jako hlavního předmětu svého zájmu a reflektovat sociální a politický kontext, v němž média fungují a který formuje charakter jejich společenského působení. Úsilí o snížení těchto rizik by mělo být provázeno úsilím o takovou změnu ekonomického, politického a mediálního systému, který umožní skutečně svobodnou a demokratickou společenskou diskusi. 


\section{Závěr}

Cíle mediální pedagogiky jsou tedy ve vztahu k symbolické moci médií dvojí. Na jedné straně stojí pedagogické úsilí o odhalování projevů a forem uplatňování symbolické moci ve společenském (mediálním) diskursu z hlediska prosazování dominantních reprezentací. To by měla být úloha především mediální socializace jako subdisciplíny mediální pedagogiky zabývající se edukačně-socializačním působením médií. Mediální výchova, jako aplikovaná disciplína rozvoje mediální gramotnosti, by pak mohla vybavit studenty takovými kompetencemi, které jim umožní identifikovat proces mediální komunikace jako nástroj uplatňování politické moci, jehož prostřednictvím je záměrně legitimizován systém moci a nadvlády. Na základě takto nabytých poznatků je pak možné porozumět tomu, jak dominantní reprezentace ovlivňují legitimizaci sociálních nerovností, jak se uplatňují v procesu sociálního vylučování a kde je v těchto výpovědích vlastní pozice jednotlivce s ohledem na jeho ekonomické a sociální zázemí, tedy jaký obraz jeho samého je mu elitami kontrolujícími média vnucován. To je předpokladem vzniku a upevnění kritického odstupu od mediálních sdělení.

Současně s tím by mělo jít úsilí o rozvoj komunikačních kompetencí vztahujících se k tvorbě sdělení a jeho distribuci a umožňujících přenést symbolickou moc jednotlivců na celospolečenskou úroveň tak, aby i zde docházelo ke střetu jednotlivých interpretací a byla zajištěna skutečná pluralita veřejné diskuse. Takto mohou jedinci zůstat autonomní vůči reprezentacím dominantní kultury, které usilují o konstruování reality podle měřítek vycházejících z potřeb mocenských elit, nepodléhat jejich formativnímu potenciálu a vytvářet adekvátní strategie obrany proti nim, včetně konstrukce vlastních kontra-tvrzení, kontra-ideologie a zakládání alternativních komunikačních platforem a struktur umožňujících účinnou obranu.

\section{Literatura}

Aufderheide, P. (1992). Media literacy. A report of the national leadership conference on media literacy. Dostupné z http://www.medialit.org/reading_room/article356.html

Bambauer, D. E. (2012). Censorship v3.1. Dostupné z http://papers.ssrn.com/sol3/papers. cfm?abstract_id $=2144004$

Berelson, B., Gaudet, H., \& Lazarsfeld, P. F. (1944). The people's choice. How the voter makes up his mind in a presidential campaign. New York: Columbia University Press.

Berger, P. L., \& Luckman, T. (1999). Sociální konstrukce reality. Pojednání o sociologii vědění. Brno: Centrum pro studium demokracie a kultury. 
Bourdieu, P. (1995). Sociální prostor a symbolická moc. In L. Bazac-Billaud, V. Hubinger, \& F. Mayer (Eds.), Antologie francouzských společenských věd: antropologie, sociologie, historie (s. 213-233). Praha: Cefres.

Bourdieu, P. (1998). Teorie jednání. Praha: Karolinum.

Castells, M. (2004). An introduction to the information age. In F. Webster \& R. Bloom (Eds.), The information society reader (s. 138-149). London: Routledge.

Fairclough, N. (2001). Critical discourse analysis as a method in social scientific research. In R. Wodak \& M. Meyer (Eds.), Methods of critical discourse analysis (s. 121-138). London: Sage.

Foucault, M. (1984). Truth and power. In P. Rabinow (Ed.), The Foucault reader (s. 51-75). New York: Pantheon Books.

Foucault, M. (2000). Dohlížet a trestat. Praha: Dauphin.

Gramsci, A. (1959). Sešity z vězení. Praha: Československý spisovatel.

Herman, E., \& Chomsky, N. (2002). Manufacturing consent. New York: Pantheon Books.

Hüther, J., \& Schorb, B. (2005). Grundbegriffe Medienpädagogik. München: Kopaed Verlags GmbH.

Jirák, J., \& Mičienka, M. (2007). Základy mediální výchovy. Praha: Portál.

Jirák, J., \& Köpplová, B. (2007). Média a společnost: stručný úvod do studia médií a mediální komunikace. Praha: Portál.

Kruger, D. (1997). Access denied. In I. Christie \& H. Perry (Eds.), Wealth and poverty of networks: Tackling social exclusion. London: Demos.

Lévy, P. (2000). Kyberkultura. Praha: Nakladatelství Karolinum.

Lohisse, J. (2003). Komunikační systémy. Praha: Karolinum.

McChesney, R. W. (2001). The political economy of media. New York: Monthly Review Press.

McNair, B. (2004). Sociologie žurnalistiky. Praha: Portál.

McQuail, D. (2009). Úvod do teorie masové komunikace. Praha: Portál.

Pospíšil, J., \& Závodná, L. S. (2009). Mediální výchova. Kralice na Hané: Computer Media.

Rámcový vzdělávací program pro gymnázia. (2007). Dostupné z http://www.vuppraha.cz/wpcontent/uploads/2009/12/RVPG-2007-07_final.pdf

Rouse, L., Thornton, B., \& Walters, B. (2006). Corporate media is corporate America. In L. Rouse, B., Thornton, \& B. Walters (Eds.), Guide corporate media ownership (s. 253-271). Dostupné z http://www.projectcensored.org/censorship/corporate-media-ownership/.

Schulz, W. (2004). Reconstructing mediatization as an analytical concept. European Journal of Communication, 19(1), 87-101.

Sloboda, Z. (2006). Mediální pedagogika. Integrující přístup k chápání a uchopování role médií ve společnosti. In R. Tichý (Ed.), Miscellanea sociologica 2006, Sborník př́spěvků z 2. doktorandské sociologické konference (s. 27-48). Praha: FSV UK.

Thompson, J. B. (2004). Média a modernita. Praha: Karolinum.

Wodak, R. (2002). Aspects of critical discourse analysis. Zeitschrift für Angewandte Linguistik, 36(10), 5-31. 


\section{Autor}

Mgr. Petr Valenta, Univerzita Karlova v Praze, Filozofická fakulta, Katedra pedagogiky,

Celetná 20, 11000 Praha 1, e-mail: val.petr@seznam.cz

\section{Symbolic power of media as an educational factor}

Abstract: The theoretical study explores media symbolic power as the main condition and means of its educational influence. The beginning of the study introduces the concept of symbolic power, from which author deduces the existence of specific media "educational program". The second part discusses the role of the state in shaping the symbolic environment and stresses the main position state holds in defining parameters of media "educational program" as a dominant hegemon of symbolic power. The possibility of creating opposition discourses potentially disruptive to symbolic hegemony of the state and the role which media education plays in this process is the topic of the next part. At the conclusion of the paper, the concept of media literacy as a social and civic competence that enables individuals to participate more effectively in the process of public communication and political decisionmaking is then formulated. Contrary to media education widespread belief that media is the hegemon of symbolic power in society, the paper proposes a theoretically substantiated thesis that the symbolic power of media is controlled by the state, which determines the content and form of public discourse. The "educational program" of media is thus controlled by the state and reflects its need to set knowledge in society. With regard to these findings, media literacy could broaden the current concept of media literacy by civic and political context. If media are primarily the domain of control, knowledge and skills associated with media should produce more accurate idea of ways power is exercised in society and forms of one's emancipation.

Keywords: symbolic power, media, ideology, discourse, institutional power, media pedagogy, media literacy

Janík, T., \& Pešková, K., et al. (2013). Školní vzdělávání: od podmínek $k$ výsledkủm. Brno: Masarykova univerzita.

Publikace prezentuje nástroje umožňující realizovat výzkum v různých oblastech školního vzdělávání, jako jsou podmínky, kurikulum, aktéři, proces a výsledky. Autoři představují kategoriální systémy, scénáře interview, dotazníky pro zkoumání různých aspektů výuky. Obsahově jsou řešena témata jako např kvalita čítanek pro primární školu, sociální klima třídy, hodnocení dětského výtvarného projevu, rozvíjení kompetence k učení apod. 